\title{
SUSTAINABILITY AND ENVIRONMENTAL INDICATORS
}

\author{
Bogdan Cristian CHIRIPUCI ${ }^{\mathrm{a}, *}$, Cristina Gabriela DUMITRU ${ }^{\mathrm{b}}$ \\ ${ }^{a), b)}$ Bucharest University of Economic Studies, Faculty of Agro-Food and \\ Environmental Economics, Bucharest, Romania
}

Please cite this article as:

Article History:

Chiripuci, B.C. and Dumitru, C.G., 2017. Sustainability and environmental indicators. Review of Economic Studies and Research Virgil Madgearu, 10(1), pp.19-26.

Received: 17 January 2017 Accepted: 7 April 2017 doi: 10.24193/RVM.2017.10.02.

Abstract: Sustainability represents the quality of human activities carried
without leading to depletion of available resources and protecting the environment
without causing any voluntary or involuntary damage. Also, it can be related to
the existence of environmental performance indicators which help preserving
certain non-renewable resources in time and space.In other words, sustainability
aims to protect the needs of future generations without compromising the natural
resources and the environment. During the World Conference on environment in
1992 in Rio de Janeiro, special attention was paid to the concept of sustainability,
which is based on the balance between environmental protection, economic growth
and finding alternative resources. Key words: sustainability; environment; trading company; responsible consumation; emissions; resources

JEL Classification: $O_{2}$; $Q_{1}$

(C) 2017 Alma Mater Publishing House. All rights reserved.

* Corresponding author. E-mail address: bogdan.chiripuci@gmail.com. 


\section{References}

1. Albu, L.L., 2006. Analize privind factorii dezvoltarii durabile pe termen foarte lung. București: Academia Română, Institutul Naţional de Cercetări Economice.

2. Government of Romania, 1999. National Strategy for Sustainable Development of Romania.

3. Man, E.T. and Mateoc-Sîrb, N., 2007.Dezvoltarea rurală şiregională durabilă a satului românesc. București: Editura Politehnica.

4. Rădulescu, C.V., 2003. Dezvoltarea durabilă şi implicaţiile economicofinanciare ale organizării exploataţiilor agricole. București: Editura ASE.

5. Rojanschi, V., Bran, F., Grigore, F. and Ioan, I., 2006. Cuantificarea dezvoltării durabile. București: Editura Economică.

6. Vădineanu, A., 1998. Dezvoltarea durabilă: teorie şi practică. București: Editura Universităţii din București. 